\title{
Teaching Methodology, Stress and Study and Learning Strategies: Interrelationships among University Students
}

\author{
Raphaela Barroso Guedes-Granzotti ${ }^{1}$ \\ Carla Patrícia Hernandez Alves Ribeiro César ${ }^{1}$ (iD \\ Vanessa Veis Ribeiro ${ }^{2}$ \\ Rodrigo Dornelas ${ }^{3}$ \\ Patricia Pinatti Moreira ${ }^{2}$ (DD \\ Kelly da Silva ${ }^{2}$
}

\begin{abstract}
Higher education can be offered by traditional or active teaching methodology, which can influence differently the study and learning strategies and the stress level of university students. This study aimed to investigate the study and learning strategies and the prevalence of stress among students of active and traditional teaching methodology and verify the influence of stress on using these strategies. 210 students in speech, language and hearing sciences from a Brazilian Federal University participated, divided into two groups, TMG (traditional methodology) and AMG (active methodology). They responded to Learning And Study Strategies Inventory and Lipp's Stress Symptom Inventory for Adults. The teaching methodology influenced the study and learning strategies, but not the stress. Stress interfered differently in the study and learning strategies depending on the teaching methodology.
\end{abstract}

Keywords: higher education, teaching methods, college students, stress, study habits

\section{Metodologia de Ensino, Estresse e Estratégias de Estudo e Aprendizagem: Interrelações em Estudantes Universitários}

\begin{abstract}
Resumo: O ensino superior pode ser oferecido por metodologia de ensino tradicional ou ativa, que podem influenciar de formas diferentes as estratégias de estudo e aprendizagem e o nível de estresse dos universitários. Este estudo teve por objetivo investigar as estratégias de estudo e aprendizagem e a prevalência de estresse entre estudantes de metodologia ativa e tradicional de ensino e verificar a influência do estresse no uso dessas estratégias. 210 estudantes de Fonoaudiologia de uma Universidade Federal brasileira, divididos em dois grupos, TMG (metodologia tradicional) e AMG (metodologia ativa), responderam o Learning And Study Strategies Inventory e o Inventário de Sintomas de Stress para Adultos de Lipp. A metodologia de ensino influenciou nas estratégias de estudo e aprendizagem, mas não no estresse. $\mathrm{O}$ estresse interferiu de forma diferente nas estratégias de estudo e aprendizagem a depender da metodologia de ensino.
\end{abstract}

Palavras-chave: ensino superior, métodos de ensino, estudantes universitários, stress, hábitos de estudo

\section{Metodología de la Enseñanza, Estrés y Estrategias de Estudio y Aprendizaje: Interrelaciones entre Estudiantes Universitarios}

\begin{abstract}
Resumen: La educación superior puede ofrecerse mediante una metodología de enseñanza tradicional o activa, que puede influir de manera distinta en las estrategias de estudio y aprendizaje y en el nivel de estrés de los estudiantes universitarios. Este estudio tuvo como objetivo investigar las estrategias de estudio y aprendizaje, la prevalencia de estrés entre los estudiantes de metodología de enseñanza activa y tradicional, así como la influencia del estrés en el uso de estas estrategias. Participaron 210 estudiantes de fonoaudiología de una Universidad Federal de Brasil, divididos en dos grupos: TMG (metodología tradicional) y AMG (metodología activa), quienes respondieron al Inventario de Estrategias de Estudio y Aprendizaje y al Inventario de Síntomas de Estrés para Adultos de Lipp. La metodología de enseñanza influyó en las estrategias de estudio y aprendizaje, pero no en el estrés. El estrés interfirió de manera diferente en las estrategias de estudio y aprendizaje según la metodología de enseñanza.
\end{abstract}

Palabras clave: educación superior, métodos de enseñanza, estudiantes universitarios, estrés, habitos de estudio

${ }^{I}$ Universidade Federal de Sergipe, São Cristóvão-SE, Brazil
${ }^{2}$ Universidade Federal de Sergipe, Lagarto-SE, Brazil
${ }^{3}$ Universidade Federal do Rio de Janeiro, Rio de Janeiro -RJ, Brazil

Correspondence address: Raphaela Barroso Guedes-Granzotti. Universidade Federal de Sergipe. Avenida Marechal Rondon, s/n, Jd. Rosa Elze, São Cristóvão-SE, Brazil. CEP 49.100-000. E-mail: raphaelabgg@gmail.com
The last decades have seen significant changes and debates in the field of Education. In this context, Active Teaching Methodologies emerge as a proposal for pedagogy based on problematization, breaking with Traditional Teaching Methodologies. The focus historically placed on learning contents has been modified to "learning to learn." 
While the Traditional Methodology is centered on the teacher and on passing on content, in which students have a passive posture receiving and memorizing information, the active methodology is centered on the student, who is daily exposed to problem situations or real scenarios and is autonomous to search for answers by making critical choices of sources and synthesizing necessary information for learning (Diesel, Baldez, \& Martins, 2017; Guedes-Granzotti et al., 2015).

Depending on the teaching methodology chosen, it is important to have a special look at the strategies that students use to study and learn. Study and learning strategies include thoughts, behaviors, opinions, or emotions that facilitate the reception, understanding, and subsequent transfer of new knowledge and skills, which are significant factors in academic performance (Jouhari, Haghani, \& Changiz, 2016). The self-regulation of learning has been studied by several researchers worldwide and one of the most used scales in university studies is the Learning and Study Strategies Inventory (LASSI) (Boruchovitch, Góes, Felicori, \& Acee, 2019; Jouhari et al., 2016; Khalil, Williams, \& Hawkins, 2018; Machado \& Boruchovitch, 2018). The LASSI aims to assess study and learning strategies in subscales divided into three components: ability (information processing, selection of main ideas, study aid), will (anxiety, attitude, and motivation) and self-regulation (concentration, time organization, concern when studying) (Jouhari et al., 2016; Khalil et al., 2018).

Besides the teaching methodology, another significant factor that can directly influence the learning process and, consequently, academic performance is the stress experienced throughout the undergraduate education, which can decrease the capacity of attention, concentration, memorization, and reasoning (J. T. Oliveira \& Bittencourt, 2015). Stress can be described as both a physiological and psychological response triggered by a stressor stimulus that requires effort from a function beyond its ability to adapt or tolerate (Lipp, 2005).

Recent studies have indicated a high prevalence of stress among university students, especially in the healthcare area. This is believed to be due to several stressors such as distance from family members, difficulty in social life, financial issues, academic overload, among others (Kam et al., 2019; Lima, Soares, Prado, \& Albuquerque, 2016; Murakami, Panúncio-Pinto, Santos, \& Troncon, 2019; E. S. Oliveira et al., 2020).

In Brazil, research on the self-regulation of studies and its applications in education is still scarce (Boruchovitch et al., 2019), and so is research on the possible factors that can influence study and learning strategies. Therefore, it is necessary to analyze and to associate the study and learning strategies and the stress prevalence of students of active and traditional teaching methodologies. However, it is important to underscore that this paper does not intend to choose one Teaching-Learning Methodology as superior to another; instead, it proposes that, in light of the results presented, discussions and reflections be raised about the study and learning strategies used by students in each teaching methodology (traditional or active). With this premise, this paper aimed to investigate the study and learning strategies and the prevalence of stress among students of active and traditional teaching methodologies and to verify the influence of stress caused by using these strategies.

\section{Method}

\section{Participants}

The participants were recruited by a direct invitation to the students of two Speech Therapy undergraduate programs of the same Brazilian Federal University, located on different campuses. One program used Traditional Teaching Methodology and the other used exclusively Active Teaching Methodologies; these methodologies are established in the Pedagogical Projects of the programs. Undergraduate students of both genders currently enrolled in Speech Therapy programs in all periods were included (to minimize confusion between the terms, the nomenclature "period" was chosen because the term "year" is used in the program with the traditional methodology and "cycle" is used in the program with active methodology). Participants who did not fill out the instruments correctly or who did not sign the informed consent form were excluded.

The sample size was calculated based on the population size. The parameters used for the calculation were: a population of 374 Speech Therapy students enrolled in the programs, 95\% confidence level and margin of sampling error of 5\%. A sample size of 210 students $(56.15 \%$ of the population) was calculated.

Thus, the sample was composed of 210 Speech Therapy students divided into two groups according to the teaching methodology used in the undergraduate program in which they were enrolled: the group of students enrolled in the program using the Traditional Teaching Methodology (TMG) and the group of students enrolled in the course using the full Active Teaching Methodologies (AMG); each group consisted of 105 students, 24 male and 81 female.

\section{Instruments}

To compare the study and learning strategies of the participating groups, the validated Brazilian Portuguese language version of the Learning and Study Strategies Inventory (LASSI) was used (Bartalo \& Guimarães, 2008). The instrument consists of 82 questions. Seventy-one questions investigate nine subscales (strategies), corresponding to concerns when studying(with two questions, enabling scores between two and ten points); anxiety, selection of the main ideas and study aids (represented by seven questions, enabling a minimum of 7 and a maximum of 35 points); attitude (eight questions ranging between eight and 40 points), concentration and time organization (nine questions, enabling between nine and 45 points), information processing and motivation (eleven questions, from 11 to 55 points). Eleven questions are related to use of the Internet in studies assessing two of the aforementioned domains: information processing and the selection of main ideas in studies that use the internet (Bartalo \& Guimarães, 2008). The description of the subscales is as follows: (1) information processing refers to the way the student uses imagery and verbal elaboration, monitors understanding and reasoning, demonstrates the zone of proximal development, and acquires, retains and applies the acquired knowledge. 
In this subscale, the lower the score, the worse the result is. (2) Anxiety measures the student's degree of concern with university and performance. The lower the score obtained, the higher the levels of tension are. (3) Time organization refers to the principles which the student uses to manage time in face of the various academic situations that he experiences, in which lower scores nest difficulties to use this strategy. (4) Concentration, which is the ability to direct and maintain attention to academic tasks, is analyzed in a way that lower scores would indicate difficulties or lack of concentration. (5) Attitude expresses the value that the student attaches to university and his interest in academic success, in which low scores indicate that the student attaches little importance to his program. (6) In concern when studying, the higher the score, the higher concern when studying is. (7) Selection of key ideas is the student's ability to identify what is most important when reading and in classes. Low scores represent difficulties in this regard. (8) Study aid designates the techniques of material support for learning and remembering new information, and low scores indicate insufficient use of study aids. (9) Motivation assesses students' diligence, self-discipline, willpower to work hard and willingness to take on full academic demands. The questions regarding use of the Internet aim to understand the study and learning strategies that students adopt when studying internet materials.

For each question, the instrument presents a five-degree Likert scale, in which number one indicates "it never happens in this way," and number five indicates "it always happens in this way." The direction of quotation of the question was inverted with the positive or negative correlation according to the domain, following inventory instructions, which was analyzed follwowing the recommendations of the literature. To obtain the scores, the Score of each subscale was added and then divided by the number of items (Bartalo \& Guimarães, 2008). The same participants also answered Lipp's Symptoms of Stress Inventory for Adults (LSSI) (Lipp, 2005). The instrument consists of physical (37 items) and psychological (19 items) symptoms of stress distributed into three frames, namely: (1) related to those experienced by the subject in the last 24 hours; (2) in the last week and (3) in the last month. The average completion time is ten minutes. Data analysis was performed according to the instrument manual. Stress was considered to exist when at least six symptoms were present in the first frame, or three of the symptoms in the table; or eight symptoms in the third frame, allowing the stage of the stress to be assessed later (with the correction procedure being executed as described in the manual) and the prevalence of the symptoms of the applicant, if needed (Lipp, 2005). The analysis was performed by a psychologist, as recommended by the second article of the Resolution of the Federal Council of Psychology n ${ }^{\circ}$ 09/2018.

\section{Procedures}

Data collection. Data collection took place in the last month before the academic recess (August 2019), the protocols were self-answered collectively in quiet, air-conditioned rooms with good lighting before the start of classes. The ISLL and LASSI questionnaires were selfanswered. First, the students were given the ISSL and then the LASSI so that there was no interference of the responses to the LASSI in the stress of the students.

Data analysis. The data of this study underwent descriptive and inferential analysis. The software used was SPSS 25.0. The description of the nominal qualitative variables was performed by means of relative and absolute frequencies. The description of continuous quantitative variables and qualitative ordinal variables was performed by means of variability measures (standard deviation), central tendency (mean and median) and position (minimum, maximum, first and third quartiles).

For the inferential analysis, the normality of the quantitative variable was tested with the Shapiro-Wilk Test. The comparison of qualitative ordinal variables and quantitative non-normal variables as a function of two independent groups was performed with the MannWhitney Test. And as a function of multiple independent groups, the comparison was performed with the KruskalWallis test. Significance values were adjusted with the Bonferroni test and multiple comparisons were performed with the Tukey Test. The association between the nominal qualitative variables of two categories was performed with Fisher's exact test, and between variables of multiple categories with Pearson's Chi-Squared test. A significance level of $5 \%$ was used.

\section{Ethical Considerations}

This study was approved by the Research Ethics Committee of Universidade Federal de Sergipe (CAAE $\mathrm{n}^{\mathrm{o}} 11632919.1 .0000 .5546$ - opinion $\left.\mathrm{n}^{\mathrm{o}} 3,377,652\right)$ and followed the recommendations of resolutions 466/12 and $510 / 16$ of the National Health Council. All participants were informed about the research and freely gave their consent by signing the TCLE.

\section{Results}

The mean age of the TMG was $22.5 \pm 6.54$ years old and the AMG 21.3 \pm 3.95 years old, with no significant difference between the groups, according to the Mann-Whitney test. The variables were distributed homogeneously among the groups, except for the higher frequency of students who attended a public high school in the AMG (Table 1).

Table 2 shows that there were significantly higher values in the following domains of LASSI: time organization and concentration in the AMG compared to the TMG.

In the AMG, $79 \%$ of the students presented results suggestive of stress and in the TMG $77.1 \%$. In both groups, the "resistance" phase was the most frequent, with prevalence of psychological symptoms. There was no association between the variables related to stress and the teaching method used in the speech therapy programs (Table 3 ). 
Table 1

Association between the nominal qualitative variables of sample characterization and the teaching method in Speech Therapy undergraduate students

\begin{tabular}{|c|c|c|c|c|c|}
\hline \multirow{2}{*}{ Variables } & \multirow{2}{*}{\multicolumn{2}{|c|}{ Categories }} & \multicolumn{2}{|c|}{ Groups } & \multirow{2}{*}{$p$-value } \\
\hline & & & TMG & AMG & \\
\hline \multirow{8}{*}{ Period } & \multirow{2}{*}{ First } & $N$ & 12 & 16 & \multirow{8}{*}{0.346} \\
\hline & & $\%$ & 11.4 & 15.2 & \\
\hline & \multirow{2}{*}{ Second } & $N$ & 27 & 36 & \\
\hline & & $\%$ & 25.7 & 34.3 & \\
\hline & \multirow{2}{*}{ Third } & $N$ & 36 & 28 & \\
\hline & & $\%$ & 34.3 & 26.7 & \\
\hline & \multirow{2}{*}{ Fourth } & $N$ & 30 & 25 & \\
\hline & & $\%$ & 28.6 & 23.8 & \\
\hline \multirow{4}{*}{ Genders } & \multirow{2}{*}{ Male } & $N$ & 24 & 24 & \multirow{4}{*}{1.000} \\
\hline & & $\%$ & 22.9 & 22.9 & \\
\hline & \multirow{2}{*}{ Female } & $N$ & 81 & 81 & \\
\hline & & $\%$ & 77.1 & 77.1 & \\
\hline \multirow{4}{*}{ Secondary Education } & \multirow{2}{*}{ Public } & $N$ & 54 & 72 & \multirow{4}{*}{$0.016^{*}$} \\
\hline & & $\%$ & 51.4 & 68.6 & \\
\hline & \multirow{2}{*}{ Particular } & $N$ & 51 & 33 & \\
\hline & & $\%$ & 48.6 & 31.4 & \\
\hline \multirow{4}{*}{ Paid Work } & \multirow{2}{*}{ No } & $N$ & 92 & 98 & \multirow{4}{*}{0.239} \\
\hline & & $\%$ & 87.6 & 93.3 & \\
\hline & \multirow{2}{*}{ Yes } & $N$ & 13 & 7 & \\
\hline & & $\%$ & 12.4 & 6.7 & \\
\hline \multirow{4}{*}{$\begin{array}{l}\text { Scholarship / } \\
\text { University aid }\end{array}$} & No & $N$ & 52 & 66 & \multirow{4}{*}{0.070} \\
\hline & \multirow{3}{*}{ Yes } & $\%$ & 49.5 & 62.9 & \\
\hline & & $N$ & 53 & 39 & \\
\hline & & $\%$ & 50.5 & 37.41 & \\
\hline
\end{tabular}

Note. Fisher's exact test; $N=$ absolute frequency; $\%=$ relative frequency percentage; TMG = group of students inserted in the Traditional Teaching Methodology; AMG = group of students inserted in the Active Teaching Methodology; * = indicates values with statistically significant difference.

Table 2

Comparison of variables related to the LASSI inventory and internet access questions according to the teaching method in Speech Therapy undergraduate students

\begin{tabular}{|c|c|c|c|c|c|c|c|c|c|c|c|c|}
\hline $\begin{array}{c}\text { Variables } \\
\text { (LASSI Subscales) }\end{array}$ & Groups & $N$ & Mean & $S D$ & Min, & Max, & $1 \mathrm{Q}$ & Median & $3 \mathrm{Q}$ & $\begin{array}{c}\text { Mann- } \\
\text { Whitney U }\end{array}$ & Z & $p$-value \\
\hline \multirow{2}{*}{ Information processing } & TMG & 105 & 3.84 & 0.65 & 2.36 & 5.00 & 3.36 & 3.91 & 4.36 & \multirow{2}{*}{4822.000} & \multirow{2}{*}{-1.570} & \multirow{2}{*}{0.116} \\
\hline & AMG & 105 & 3.72 & 0.64 & 1.82 & 5.00 & 3.27 & 3.73 & 4.14 & & & \\
\hline \multirow{2}{*}{ Anxiety } & TMG & 105 & 3.03 & 0.64 & 1.57 & 4.43 & 2.57 & 3.00 & 3.57 & \multirow{2}{*}{5090.500} & \multirow{2}{*}{-0.961} & \multirow{2}{*}{0.337} \\
\hline & AMG & 105 & 2.96 & 0.61 & 1.43 & 4.14 & 2.50 & 2.86 & 3.43 & & & \\
\hline \multirow{2}{*}{ Time Organization } & TMG & 105 & 2.97 & 0.64 & 1.33 & 4.56 & 2.56 & 2.89 & 3.44 & \multirow{2}{*}{4522.500} & \multirow{2}{*}{-2.252} & \multirow{2}{*}{$0.024 *$} \\
\hline & $\mathrm{AMG}$ & 105 & 3.15 & 0.58 & 1.67 & 4.44 & 2.78 & 3.22 & 3.56 & & & \\
\hline \multirow{2}{*}{ Concentration } & $\mathrm{TMG}$ & 105 & 3.53 & 0.69 & 1.89 & 5.00 & 3.00 & 3.67 & 4.00 & \multirow{2}{*}{4522.500} & \multirow{2}{*}{-2.252} & \multirow{2}{*}{$0.024 *$} \\
\hline & AMG & 105 & 3.73 & 0.68 & 1.22 & 5.00 & 3.33 & 3.89 & 4.11 & & & \\
\hline \multirow{2}{*}{ Attitude } & TMG & 105 & 4.21 & 0.67 & 1.88 & 5.00 & 4.00 & 4.38 & 4.63 & \multirow{2}{*}{5398.000} & \multirow{2}{*}{-0.261} & \multirow{2}{*}{0.794} \\
\hline & AMG & 105 & 4.24 & 0.56 & 2.25 & 5.25 & 4.00 & 4.38 & 4.63 & & & \\
\hline \multirow{2}{*}{ Concern when studying } & TMG & 105 & 4.06 & 1.07 & 1.00 & 5.00 & 3.50 & 4.50 & 5.00 & \multirow{2}{*}{4862.000} & \multirow{2}{*}{-1.517} & \multirow{2}{*}{0.129} \\
\hline & AMG & 105 & 3.89 & 1.02 & 1.00 & 5.00 & 3.00 & 4.00 & 5.00 & & & \\
\hline \multirow{2}{*}{ Selection of main ideas } & TMG & 105 & 3.51 & 0.75 & 1.57 & 5.00 & 3.00 & 3.57 & 4.07 & \multirow{2}{*}{5045.500} & \multirow{2}{*}{-1.063} & \multirow{2}{*}{0.288} \\
\hline & $\mathrm{AMG}$ & 105 & 3.40 & 0.75 & 1.43 & 5.00 & 2.86 & 3.43 & 3.86 & & & \\
\hline \multirow{2}{*}{ Study aid } & TMG & 105 & 3.53 & 0.71 & 1.86 & 5.00 & 3.07 & 3.43 & 4.14 & \multirow{2}{*}{4954.000} & \multirow{2}{*}{-1.271} & 0.204 \\
\hline & AMG & 105 & 3.39 & 0.69 & 1.71 & 4.71 & 2.86 & 3.43 & 3.93 & & & \\
\hline Motivation & TMG & 105 & 3.49 & 0.46 & 2.09 & 4.45 & 3.23 & 3.55 & 3.82 & 4062000 & & \\
\hline Motivation & $\mathrm{AMG}$ & 105 & 3.58 & 0.45 & 2.27 & 4.73 & 3.23 & 3.55 & 3.91 & 4963.000 & & \\
\hline Internet questions & TMG & 105 & 30.23 & 7.87 & 0.00 & 40.00 & 26.00 & 31.00 & 36.00 & 4087000 & & \\
\hline Information processing & $\mathrm{AMG}$ & 105 & 29.70 & 6.81 & 0.00 & 40.00 & 25.00 & 29.00 & 35.00 & $498 / .000$ & -1.195 & 0.232 \\
\hline Internet questions & TMG & 105 & 10.85 & 3.12 & 0.00 & 15.00 & 9.00 & 11.00 & 13.00 & 5478.500 & -0.078 & 0.938 \\
\hline Selection of general ideas & $\mathrm{AMG}$ & 105 & 10.78 & 3.18 & 0.00 & 15.00 & 8.50 & 11.00 & 13.00 & & & \\
\hline
\end{tabular}

Note. Mann-Whitney Test; AMG = group of students inserted in the Active Teaching Methodology; $S D=$ standard deviation; LASSI = Learning and Study Strategies Inventory; $N=$ absolute frequency; TMG = group of students inserted in the Traditional Teaching Methodology; Min. $=$ minimum $;$ Max.$=$ maximum $; *=$ indicates values with statistically significant difference. 
Table 3

Association between the variables related to the ISSL inventory and the teaching method in Speech Therapy undergraduate students

\begin{tabular}{|c|c|c|c|c|c|}
\hline \multirow{2}{*}{ Variables } & \multirow{2}{*}{ Categories } & & \multicolumn{2}{|c|}{ Study groups } & \multirow{2}{*}{$p$-value } \\
\hline & & & TMG & AMG & \\
\hline \multirow{4}{*}{ Presence or not of stress } & & $N$ & 24 & 22 & \multirow{4}{*}{0.868} \\
\hline & Stress-free & $\%$ & 22.9 & 21.0 & \\
\hline & & $N$ & 81 & 83 & \\
\hline & With stress & $\%$ & 77.1 & 79.0 & \\
\hline \multirow{8}{*}{ ISSL Stress Phases } & Alert & $N$ & 2 & 0 & \multirow{8}{*}{0.474} \\
\hline & Alert & $\%$ & 2.5 & 0.0 & \\
\hline & Resistance & $N$ & 64 & 69 & \\
\hline & Resistance & $\%$ & 79.0 & 82.1 & \\
\hline & & $N$ & 14 & 13 & \\
\hline & Near exhaustion & $\%$ & 17.3 & 15.5 & \\
\hline & \multirow{2}{*}{ Exhaustion } & $N$ & 1 & 2 & \\
\hline & & $\%$ & 1.2 & 2.4 & \\
\hline \multirow{5}{*}{$\begin{array}{l}\text { Predominance of Stress } \\
\text { Symptoms }\end{array}$} & Psychological & $\begin{array}{l}N \\
\%\end{array}$ & $\begin{array}{c}52 \\
64.2\end{array}$ & $\begin{array}{c}52 \\
61.9\end{array}$ & \multirow{5}{*}{0.380} \\
\hline & Physical & $N$ & 15 & 22 & \\
\hline & Physical & $\%$ & 18.5 & 26.2 & \\
\hline & Psychological and & $N$ & 14 & 10 & \\
\hline & physical & $\%$ & 17.3 & 11.9 & \\
\hline
\end{tabular}

Note. Fisher's exact and Chi-square tests; AMG = group of students inserted in the Active Teaching Methodology; ISSL Lipp's Inventory of Symptoms of Stress for Adults; $N=$ absolute frequency; TMG = group of students inserted in the Traditional Teaching Methodology; $\%=$ percentage relative frequency.

Table 4 shows that TMG students with stress presented significantly lower values in the factors anxiety, time organization, concentration and attitude than students without stress. This shows that students with stress have a higher level of anxiety and less ability to organize time, concentration and attitude when studying.

In the AMG, students with stress presented significantly lower scores in the factors anxiety, which indicates a higher level of anxiety, and lower score in motivation (which indicates less motivation) of LASSI, than students without stress, as shown in Table 5 .

There was no significant difference in LASSI scores and internet access questions due to the predominance factor of stress symptoms in undergraduate students of Speech Therapy of the TMG and the AMG with stress.

It was not possible to compare the scores in the LASSI subscales with the stress phases due to the low number of participants in the alert and exhaustion phases.

Table 4

Comparison of variables related to the LASSI inventory and internet access questions according to the teaching method in Speech Therapy undergraduate students

\begin{tabular}{|c|c|c|c|c|c|c|c|c|c|c|c|c|}
\hline$\frac{\text { Variables }}{\text { (LASSI Subscales) }}$ & Stress & $N$ & Mean & $S D$ & Minimum & Maximum & $1 \mathrm{Q}$ & Median & $3 Q$ & $\begin{array}{c}\text { Mann- } \\
\text { Whitney U }\end{array}$ & $\mathrm{Z}$ & $p$-value \\
\hline \multirow{2}{*}{$\begin{array}{l}\text { Information } \\
\text { processing }\end{array}$} & Without & 24 & 4.05 & 0.61 & 2.36 & 5.00 & 3.77 & 4.18 & 4.45 & \multirow{2}{*}{715.500} & \multirow{2}{*}{-1.959} & \multirow{2}{*}{0.050} \\
\hline & With & 81 & 3.78 & 0.65 & 2.36 & 5.00 & 3.27 & 3.82 & 4.27 & & & \\
\hline \multirow{2}{*}{ Anxiety } & Without & 24 & 3.48 & 0.62 & 1.71 & 4.43 & 3.32 & 3.57 & 3.86 & \multirow{2}{*}{439.500} & \multirow{2}{*}{-4.075} & \multirow{2}{*}{$<0.001 *$} \\
\hline & With & 81 & 2.90 & 0.59 & 1.57 & 4.14 & 2.50 & 2.86 & 3.43 & & & \\
\hline \multirow{2}{*}{ Time Organization } & Without & 24 & 3.22 & 0.72 & 1.44 & 4.33 & 2.61 & 3.33 & 3.86 & \multirow{2}{*}{671.500} & \multirow{2}{*}{-2.297} & \multirow{2}{*}{$0.022 *$} \\
\hline & With & 81 & 2.90 & 0.60 & 1.33 & 4.56 & 2.44 & 2.89 & 3.28 & & & \\
\hline \multirow{2}{*}{ Concentration } & Without & 24 & 3.93 & 0.75 & 2.00 & 5.00 & 3.36 & 4.06 & 4.56 & \multirow{2}{*}{561.500} & \multirow{2}{*}{-3.138} & \multirow{2}{*}{$0.002 *$} \\
\hline & With & 81 & 3.42 & 0.63 & 1.89 & 4.67 & 3.00 & 3.56 & 3.89 & & & \\
\hline \multirow{2}{*}{ Attitude } & Without & 24 & 4.33 & 0.79 & 1.88 & 5.00 & 4.16 & 4.63 & 4.84 & \multirow{2}{*}{713.500} & \multirow{2}{*}{-1.981} & \multirow{2}{*}{$0.048^{*}$} \\
\hline & With & 81 & 4.17 & 0.64 & 2.50 & 5.00 & 4.00 & 4.38 & 4.63 & & & \\
\hline \multirow{2}{*}{$\begin{array}{l}\text { Concern when } \\
\text { studying }\end{array}$} & Without & 24 & 4.15 & 1.01 & 1.50 & 5.00 & 4.00 & 4.25 & 5.00 & \multirow{2}{*}{921.500} & \multirow{2}{*}{-0.400} & \multirow{2}{*}{0.689} \\
\hline & With & 81 & 4.03 & 1.09 & 1.00 & 5.00 & 3.50 & 4.50 & 5.00 & & & \\
\hline \multirow{2}{*}{$\begin{array}{l}\text { Selection of main } \\
\text { ideas }\end{array}$} & Without & 24 & 3.74 & 0.73 & 1.86 & 5.00 & 3.18 & 3.79 & 4.39 & \multirow{2}{*}{744.000} & \multirow{2}{*}{-1.743} & \multirow{2}{*}{0.081} \\
\hline & With & 81 & 3.44 & 0.75 & 1.57 & 5.00 & 2.86 & 3.43 & 4.00 & & & \\
\hline
\end{tabular}


Table 4

Continuation

\begin{tabular}{|c|c|c|c|c|c|c|c|c|c|c|c|c|}
\hline$\frac{\text { Variables }}{\text { (LASSI Subscales) }}$ & Stress & $N$ & Mean & $S D$ & Minimum & Maximum & $1 \mathrm{Q}$ & Median & $3 Q$ & $\begin{array}{c}\text { Mann- } \\
\text { Whitney U }\end{array}$ & Z & $p$-value \\
\hline \multirow{2}{*}{ Study aid } & Without & 24 & 3.55 & 0.75 & 1.86 & 4.86 & 3.18 & 3.64 & 4.07 & \multirow{2}{*}{913.500} & \multirow{2}{*}{-0.447} & \multirow{2}{*}{0.655} \\
\hline & With & 81 & 3.53 & 0.70 & 2.00 & 5.00 & 3.00 & 3.43 & 4.14 & & & \\
\hline \multirow{2}{*}{ Motivation } & Without & 24 & 3.67 & 0.51 & 2.64 & 4.45 & 3.27 & 3.68 & 3.98 & \multirow{2}{*}{732.000} & \multirow{2}{*}{-1.836} & \multirow{2}{*}{0.066} \\
\hline & With & 81 & 3.44 & 0.44 & 2.09 & 4.18 & 3.14 & 3.45 & 3.73 & & & \\
\hline \multirow{2}{*}{$\begin{array}{l}\text { Internet questions } \\
\text { Information } \\
\text { processing }\end{array}$} & Without & 24 & 29.42 & 10.27 & 0.00 & 39.00 & 27.25 & 31.50 & 36.75 & \multirow[b]{2}{*}{961.000} & \multirow[b]{2}{*}{-0.084} & \multirow[b]{2}{*}{0.933} \\
\hline & With & 81 & 30.47 & 7.07 & 0.00 & 40.00 & 26.00 & 31.00 & 36.00 & & & \\
\hline \multirow{2}{*}{$\begin{array}{l}\text { Internet questions } \\
\text { Selection of general } \\
\text { ideas }\end{array}$} & Without & 24 & 10.58 & 4.01 & 0.00 & 15.00 & 9.00 & 11.00 & 13.00 & \multirow[b]{2}{*}{971.000} & \multirow[b]{2}{*}{-0.008} & \multirow[b]{2}{*}{0.994} \\
\hline & With & 81 & 10.93 & 2.82 & 0.00 & 15.00 & 9.00 & 11.00 & 13.00 & & & \\
\hline
\end{tabular}

Note. Mann-Whitney Test; $N=$ absolute frequency; $S D=$ standard deviation; LASSI = Learning and Study Strategies Inventory; $*=$ indicates values with statistically significant difference.

Table 5

Comparison of variables related to the LASSI inventory and internet access questions according to the teaching method in Speech Therapy undergraduate students in the $A M G$

\begin{tabular}{|c|c|c|c|c|c|c|c|c|c|c|c|c|}
\hline$\frac{\text { Variables }}{\text { (LASSI Subscales) }}$ & Stress & $N$ & Mean & $S D$ & Minimum & Maximum & $1 \mathrm{Q}$ & Median & $3 \mathrm{Q}$ & $\begin{array}{c}\text { Mann- } \\
\text { Whitney U }\end{array}$ & Z & $p$-value \\
\hline \multirow{2}{*}{$\begin{array}{l}\text { Information } \\
\text { processing }\end{array}$} & Without & 22 & 3.59 & 0.55 & 2.18 & 4.45 & 3.25 & 3.59 & 3.91 & \multirow{2}{*}{772.000} & \multirow{2}{*}{-1.112} & \multirow{2}{*}{0.266} \\
\hline & With & 83 & 3.75 & 0.66 & 1.82 & 5.00 & 3.27 & 3.73 & 4.18 & & & \\
\hline \multirow{2}{*}{ Anxiety } & Without & 22 & 3.29 & 0.50 & 2.43 & 4.14 & 3.00 & 3.36 & 3.61 & \multirow{2}{*}{560.500} & \multirow{2}{*}{-2.785} & \multirow{2}{*}{$0.005^{*}$} \\
\hline & With & 83 & 2.87 & 0.61 & 1.43 & 4.14 & 2.43 & 2.71 & 3.43 & & & \\
\hline \multirow{2}{*}{ Time Organization } & Without & 22 & 3.16 & 0.39 & 2.11 & 3.67 & 3.06 & 3.22 & 3.36 & \multirow{2}{*}{906.500} & \multirow{2}{*}{-0.051} & \multirow{2}{*}{0.959} \\
\hline & With & 83 & 3.15 & 0.62 & 1.67 & 4.44 & 2.67 & 3.22 & 3.67 & & & \\
\hline \multirow{2}{*}{ Concentration } & Without & 22 & 3.89 & 0.42 & 3.22 & 4.89 & 3.56 & 3.89 & 4.11 & \multirow{2}{*}{788.000} & \multirow{2}{*}{-0.986} & \multirow{2}{*}{0.324} \\
\hline & With & 83 & 3.68 & 0.73 & 1.22 & 5.00 & 3.22 & 3.89 & 4.11 & & & \\
\hline \multirow{2}{*}{ Attitude } & Without & 22 & 4.20 & 0.58 & 2.25 & 5.00 & 4.09 & 4.31 & 4.50 & \multirow{2}{*}{844.500} & \multirow{2}{*}{-0.541} & \multirow{2}{*}{0.588} \\
\hline & With & 83 & 4.25 & 0.56 & 2.75 & 5.25 & 3.88 & 4.38 & 4.63 & & & \\
\hline \multirow{2}{*}{$\begin{array}{l}\text { Concern when } \\
\text { studying }\end{array}$} & Without & 22 & 3.93 & 1.09 & 1.50 & 5.00 & 3.38 & 4.00 & 5.00 & \multirow{2}{*}{868.000} & \multirow{2}{*}{-0.361} & \multirow{2}{*}{0.718} \\
\hline & With & 83 & 3.88 & 1.01 & 1.00 & 5.00 & 3.00 & 4.00 & 5.00 & & & \\
\hline \multirow{2}{*}{$\begin{array}{l}\text { Selection of main } \\
\text { ideas }\end{array}$} & Without & 22 & 3.62 & 0.66 & 2.43 & 4.86 & 3.29 & 3.57 & 4.04 & \multirow{2}{*}{724.000} & \multirow{2}{*}{-1.491} & \multirow{2}{*}{0.136} \\
\hline & With & 83 & 3.35 & 0.77 & 1.43 & 5.00 & 2.86 & 3.43 & 3.86 & & & \\
\hline \multirow{2}{*}{ Study aid } & Without & 22 & 3.24 & 0.72 & 1.71 & 4.43 & 2.82 & 3.14 & 4.00 & \multirow{2}{*}{764.500} & \multirow{2}{*}{-1.173} & 0241 \\
\hline & With & 83 & 3.43 & 0.68 & 1.71 & 4.71 & 2.86 & 3.43 & 3.86 & & & \\
\hline Motiuntion & Without & 22 & 3.74 & 0.36 & 3.09 & 4.36 & 3.55 & 3.82 & 4.09 & $6580 \cap 0$ & & \\
\hline 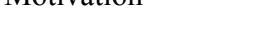 & With & 83 & 3.53 & 0.47 & 2.27 & 4.73 & 3.18 & 3.55 & 3.91 & 050.000 & & \\
\hline Internet questions & Without & 22 & 26.95 & 8.01 & 0.00 & 36.00 & 25.00 & 29.00 & 31.25 & & & \\
\hline $\begin{array}{l}\text { Information } \\
\text { processing }\end{array}$ & With & 83 & 30.42 & 6.31 & 14.00 & 40.00 & 25.00 & 30.00 & 37.00 & 723.000 & -1.500 & 0.134 \\
\hline Internet questions & Without & 22 & 10.45 & 3.50 & 0.00 & 15.00 & 8.00 & 11.50 & 12.25 & & & \\
\hline $\begin{array}{l}\text { Selection of general } \\
\text { ideas }\end{array}$ & With & 83 & 10.87 & 3.11 & 3.00 & 15.00 & 9.00 & 11.00 & 13.00 & 864.000 & -0.388 & 0.698 \\
\hline
\end{tabular}

Note. Mann-Whitney Test; AMG = group of students inserted in the Active Teaching Methodology; $S D=$ standard deviation; LASSI = Learning and Study Strategies Inventory; $N=$ absolute frequency; * = indicates values with statistically significant difference. 


\section{Discussion}

The general objective of the research was to verify the study and learning strategies used by Speech Therapy students and the relationship with the prevalence of stress according to the teaching methodology used in the undergraduate program.

The comparison between the groups regarding the study and learning strategies used by the students shows that in the program using Active Teaching Methodologies, students presented significantly better scores regarding time organization and concentration than the students in the program using Traditional Teaching Methodology.

Some hypotheses can be considered to understand this result. The first is that the programs using only full active methodologies do so in small groups, with problem situations close to professional reality, and the students share responsibility for their own learning. In this way, they need to organize their study time and materials, establish the main ideas of the studied subject so that they can present them to the group. In addition, when in group discussion they need to focus to present what has not yet been discussed, to address in depth topics already discussed or even refute theoretical assumptions. This need can enable such skills to be honed earlier in students inserted in this methodology, from the intial periods of their program (Guedes-Granzotti et al., 2015).

Regarding the presence of signs suggesting stress, high prevalence was observed in both groups studied, regardless of the study method they are experiencing in their undergraduate program. These findings corroborate several recent studies, mainly in healthcare students, which observed high prevalence, between $60.1 \%$ (Lima et al., 2016) and 70\% (Murakami et al., 2019), although they are still lower than the findings in this study. Compared with studies involving students from other areas, there is a tendency to observe lower prevalence of stress (Lameu, Salazar, \& Souza, 2016; Paiva, Parente, Brandão \& Queiroz, 2014) than studies conducted with healthcare students. Higher prevalence of stress in healthcare students (Kam et al., 2019; Lima et al., 2016; Murakami et al., 2019).

One of the factors that may have influenced the high prevalence of stress is the fact that the questionnaires of this research were applied at the end of the college semester, which is usually a period with a larger number of activities that need to be completed and when the tests are concentrated, therefore with more stressful events.

Most students with stress are in the resistance phase and have a predominance of psychological symptoms similar to those reported in several other studies, although with different percentages (Kam et al., 2019; Lameu et al., 2016; Lima et al., 2016; Murakami et al., 2019). Therefore, it can be inferred that most university students have the resources to cope with stressful events (Lameu et al., 2016), considering that the resistance phase is thought to be an attempt at physical and mental rebalancing in which the organism changes its parameters of normality and concentrates the internal reaction on a certain target organ (Lipp, 2005).

Although the teaching methodology did not influence the prevalence of stress in this study, it is known that several factors can lead students to psychic suffering through university life, generating common mental disorders such as anxiety and depression. Brazilian rates are higher than those among the general population (Graner \& Cerqueira, 2019). It can be said that stress is a factor that contributes to vulnerability (Lameu et al., 2016; Padovani et al., 2014), and adds to the plurality of aspects that can interfere in the learning process, training and psycho-emotional development of university students. When a student is in the resistance phase, even if they are capable of coping and adapting to stress, they may present learning difficulties and academic failure, mainly due to the feeling of constant physical exhaustion and memory problems (Lameu et al., 2016).

Regarding the learning components, it was observed that the "skills" component, which in the version of the LASSI used in this research includes the domains related to information processing and selection of main ideas, was not statistically different between students with and without stress, regardless of the teaching methodology in use. This suggests that neither stress nor methodology influence this component.

The "will" domain, however, was influenced by stress in both study groups. The TMG had all aspects of this component affected (anxiety, attitude and motivation) and the AMG had two (anxiety and motivation). However, in the "self-regulation" component, people with stress inserted in the TMG also presented worse results in time organization strategies and selfregulation. Such results were not found in AMG students.

Thus, the perspective of this study allowed the observation that the impact of stress on study and learning strategies interfered differently between students of the program using active methodologies and students of the program using the traditional methodology.

Analyzing individually the categories within each component of the study and learning strategies, it was possible to observe that the presence of stress significantly influenced the presence of anxiety in both groups. This shows that university students are experiencing high levels of tension associated with university and their own performance (Bartalo \& Guimarães, 2008). These findings are consistent with the literature which identifies stress as a factor that predisposes to the emergence of anxiety disorders. Although common and possibly as debilitating as depression, it has been less discussed (Quek et al., 2019), but is no less important for academic performance.

Among the university students in programs using active methodologies, it was observed that in addition to anxiety, stress significantly influenced motivation. This finding corroborates other studies (Karaman \& Watson, 2017; Trigueros et al., 2020) which observed that stress can negatively predict students' motivation. One hypothesis that can be suggested to explain why stress only influenced the motivation of students of active methodology is that, in this pedagogical approach, based on problematization, students are responsible for solving problems and searching for the contents to be studied, and difficulties in problem-solving situations can lead to demotivation (Franzen, Bercht, \& Dertzbacher, 2017; Guedes-Granzotti et al., 2015). 
Particularly concerning attitude, which expresses the value that a student attaches to university and their interest in academic success of (Bartalo \& Guimaraes, 2008), and which proved to be related to stress among the students in the TMG, it can be understood as the loyalty and commitment of students to their institutions of learning; in other words, through attitude the student adds the institution's brand to their own image, as found by researchers (Grewal \& Santana, 2017) analyzing whether university students used the brands of their institutions of learning on social media. They concluded that students appropriate several elements of the brand such as logo, color, clothing (jackets, t-shirts, among other things), and façade. This is because, according to the authors, by posting photographs on digital social networks with institutional brands, and linking their symbolic values to those of their own image, they are contributing in this way to creating the individual's identity. The confirmed hypotheses that stimulate such behaviors in university students were that the perception of the quality of the program and the higher education institution and emotional commitment have a direct impact on loyalty (Torres \& Brasil, 2009); that is, the value that the student attributes to his university, corroborating our findings that stress interfered in how the university is perceived.

However, it is noted that this is a poorly studied topic in the field of Education, and it is essential that new studies deepen investigations about it, especially in institutional selfassessments, since decreased scores in attitude can lead to dropping out and negative evaluations of the institution itself.

The significant difficulty to concentrate observed in students with stress in the TMG, as well as the anxiety observed in students of both groups with stress, is seen as a characteristic symptom of the resistance phase (Lipp, 2005), the phase in which the vast majority of students are. In this phase, when the stressor remains either for a long period or when it occurs in great intensity, a person may experience tiredness, irritability, anxiety, fear, social isolation, appetite oscillation, sexual impotence and mood swings (Lipp, 2005).

As for time organization, also related to stress only in the TMG, it can be explained by the fact that the program using traditional teaching methodology is located in the state capital, with many places for internships and different clinical practices that require daily urban locomotion and can be described as a stressor caused by city living, such as transportation delay, crowded, uncomfortable buses and traffic that can hinder time organization. The program using active teaching methodology, in turn, is located in the state countryside, and most of the learning spaces are located within the University or very close. These findings contribute to broadening the discussion of other studies that showed the difficulty of urban mobility as a stress factor. (Mussi et al., 2019).

The high prevalence of people with stress in both methodologies of this study indicates the need for new studies to know the stress factors and to establish a causal relationship between them. Such data may contribute directly to the institutional diagnosis and to create strategies to promote students' mental health. In addition, the results demonstrate the importance of identifying the strengths and weaknesses related to study and learning strategies that need more attention in each teaching methodology, inspiring the creation of actions that aim to optimize the strategies used successfully and to discuss those that need more monitoring.

Despite the contributions of this study on the relationship between different teaching methodologies, stress, study and learning strategies used by students in their majors, especially considering the scarcity of studies in the area, it is important to consider some limitations. One is that the sample consisted only of Speech Therapy undergraduate students, which does not allow the findings to be generalized to all university students.

Another limitation was the fact that the possible stress agents and the possible actions taken by students to cope with stress were not assessed. These are factors that can influence study and learning strategies in different ways. New studies are needed to minimize these limitations and enable further reflections on the influence of teaching methodologies in the process of university education.

\section{References}

Bartalo, L., \& Guimarães, S. E. R. (2008). Estratégias de estudo e aprendizagem de alunos universitários: Um estudo exploratório [Study and learning strategies for university students: An exploratory study]. Informação \& Informação, 13(2), 1-14. doi:10.5433/1981-8920.2008v13n2p1

Boruchovitch, E., Góes, N. M., Felicori, C. M., \& Acee, T. W. (2019). Translation and adaptation of the learning and study strategies Inventory - lassi 3rd edition for use in Brazil: Methodological considerations. Educação em Análise, 4(1), 7-20. doi:10.5433/1984-7939.2019v4n1p7

Cardoso, J. B. F., \& Santana, J.A. (2017). Brazilian universities' brands in Instagram: The student's discourse and identity. Teknokultura, 14(2), 241-259. doi:10.5209/TEKN.54861

Diesel, A., Baldez, A. L. S., \& Martins, S. N. (2017). Os princípios das metodologias ativas de ensino: Uma abordagem teórica [Active teaching methodologies principles: A theoretical approach]. Revista Thema, 14(1), 268-288. doi:10.15536/thema.14.2017.268-288.404

Franzen, E., Bercht, M., \& Dertzbacher, J. (2017). Problematização aplicada ao ensino e aprendizagem de algoritmos: Uma análise dos fatores associados a motivação dos estudantes [Problematization applied to teach and learn algorithms: An analysis of the factors associated with student motivation]. Renote - Revista Novas Tecnologias na Educação, 15(1), 1-10. doi:10.22456/1679-1916.75148

Graner, K. M., \& Cerqueira, A. T. A. R. (2019). Revisão integrativa: Sofrimento psíquico em estudantes universitários e fatores associados [Integrative review: Psychological distress among university students and correlated factors]. Ciência \& Saúde Coletiva, 24(4), 1327-1346. doi:10.1590/1413-81232018244.09692017 
Guedes-Granzotti, R. B., Silva, K., Dornelas, R., Cesar, C. P. H. A. R., Pellicani, A. D., \& Domenis, D. R. (2015). Problem-situation as a trigger of the teaching-learning process in active teaching methodologies. Revista CEFAC, 17(6), 2081-2087. doi:10.1590/1982-021620151768015

Jouhari, K., Haghani, F., \& Changiz, T. (2016). Assessment of medical students' learning and study strategies in self-regulated learning. Journal of Advances in Medical Education \& Professionalism, 4(2), 72-79. Retrieved from https:/www.ncbi.nlm.nih.gov/pmc/articles/PMC4827759/ pdf/jamp-4-72.pdf

Kam, S. X. L., Toledo, A. L. S., Pacheco, C. C., Souza, G. F. B., Santana, V. L. M., Bonfá-Araujo, B., \& Custódio, C. R. S. N. (2019). Estresse em estudantes ao longo da graduação médica [Stress in undergraduate medical students]. Revista Brasileira de Educação Médica, 43(1 Suppl. 1), 246-253. doi:10.1590/ 1981-5271v43suplemento1-20180192

Karaman, M. A., \& Watson, J. W. (2017). Examining associations among achievement motivation, locus of control, academic stress, and life satisfaction: A comparison of U.S. and international undergraduate students. Personality and Individual Differences, 111, 106-110. doi:10.1016/j.paid.2017.02.006

Khalil, M. K., Williams, S. E., \& Hawkins, H. G. (2018). Learning and study strategies correlate with medical students' performance in anatomical sciences. Anatomical Sciences Education, 11(3), 236-242. doi:10.1002/ ase. 1742

Lameu, J. N., Salazar, T. L., \& Souza, W. F. (2016). Prevalência de sintomas de stress entre graduandos de uma universidade pública [Prevalence of stress symptoms among students of a public university]. Psicologia da Educação, (42), 13-22. doi:10.5935/21753520.20150021

Lima, R. L., Soares M. E. C., Prado, S. N., \& Albuquerque, G. S. C. (2016). Estresse do estudante de medicina e rendimento acadêmico [Stress among medical students and academic performance]. Revista Brasileira de Educação Médica, 40(4), 678-684. doi:10.1590/ 1981-52712015v40n4e 01532015

Lipp, M. E. N. (2005). Manual do inventário de sintomas de stress para adultos de Lipp (ISSL) [Lipp's inventory of symptoms of stress for adults (ISSL) manual]. São Paulo, SP: Casa do Psicólogo.

Machado, A. C. T. A., \& Boruchovitch, E. (2018). Promovendo a autorregulação da aprendizagem em sala de aula: Considerações sobre modelos de intervenção e a formação de professores [Promoting selfregulated learning in the classroom: Considerations on intervention models and teacher education]. Revista de Educação PUC-Campinas, 23(3), 337-348. doi:10.24220/2318-0870v23n3a4107
Mussi, F. C., Pires, C. G. S., Carneiro, L. S., Costa, A. L. S., Ribeiro, F. M. S. S., \& Santos, A. F. (2019). Comparison of stress in freshman and senior nursing students. Revista da Escola de Enfermagem da USP, 53, e03431. doi:10.1590/S1980-220X2017023503431

Murakami, K., Panúncio-Pinto, M. P., Santos, J. L. F., \& Troncon, L. E. A. (2019). Psychological stress in students from undergraduate courses in health professions: Contribution to promote mental health. Revista de Medicina, 98(2), 108-113. doi:10.11606/issn.1679-9836. v98i2p108-113

Oliveira, E. S., Silva, A. F. R., Silva, K. C. B., Moura, T. V. C., Araújo, A. L., \& Silva, A. R. V. (2020). Stress and health risk behaviors among university students. Revista Brasileira de Enfermagem, 73(1), e20180035. doi:10.1590/0034-7167-2018-0035

Oliveira, J. T., \& Bittencourt, Z. Z. L. C. (2015). Atividades extracurriculares e qualidade de vida de alunos de fonoaudiologia [Extra-curricular activities and quality of life of speech therapy's students]. Serviço Social \& Saúde, 13(1), 141-150. doi:10.20396/sss.v13i1.8634926

Padovani, R. C., Neufeld, C. B., Maltoni, J., Barbosa, L. N. F., Souza, W. F., Cavalcanti, H. A. F., \& Lameu, J. N. (2014). Vulnerabilidade e bem-estar psicológicos do estudante universitário [Vulnerability and psychological well-being of college student]. Revista Brasileira de Terapias Cognitivas, 10(1), 2-10. doi:10.5935/ 1808-5687.20140002

Paiva, M. R. F., Parente, J. R. F., Brandão, I. R., \& Queiroz, A. H. B. (2016). Metodologias ativas de ensino-aprendizagem: Revisão integrativa [Active teaching-learning methodologies: Integrative review]. SANARE: Revista de Políticas Públicas, 15(2), 145-153. Retrieved from https://sanare.emnuvens.com.br/sanare/ article/view/1049

Quek, T. T., Tam, W. W., Tran, B. X., Zhang, M., Zhang, Z., Ho, C. S., \& Ho, R. C. (2019). The global prevalence of anxiety among medical. International Journal of Environmental Research and Public Health, 16(15), 2735. doi:10.3390/ijerph16152735

Trigueros, R., Padilla, A., Aguilar-Parra, J. M., Lirola, M. J., García-Luengo, A. V., Rocamora-Pérez, P., \& LópezLiria, R. (2020). The influence of teachers on motivation and academic stress and their effect on the learning strategies of university students. International Journal of Environmental Research and Public Health, 17(23), 9089. doi:10.3390/ijerph17239089

Torres, L. M., \& Brasil, V. S. (2009). Validação de um modelo de lealdade do estudante com base na qualidade do relacionamento [The validation of a student loyalty model based on relationship quality]. Revista de Administração FACES Journal, 8(3), 119-137. https:// www.redalyc.org/pdf/1940/194016889009.pdf 
Raphaela Barroso Guedes-Granzotti is a Professor of the Department of Speech-Language Pathology at Universidade Federal de Sergipe, São Cristóvão-SE, Brazil.

Carla Patrícia Hernandez Alves Ribeiro César is a Professor of the Department of Speech-Language Pathology at Universidade Federal de Sergipe, São Cristóvão-SE, Brazil.

Vanessa Veis Ribeiro is a Professor of the Department of Speech-Language Pathology at Universidade Federal de Sergipe, Lagarto-SE, Brazil.

Rodrigo Dornelas is a Professor of the Department of Speech-Language Pathology at Universidade Federal do Rio de Janeiro, Rio de Janeiro-RJ, Brazil.

Patricia Pinatti Moreira is a Professor of the Universidade Federal de Sergipe, Lagarto-SE, Brazil.

Kelly da Silva is a Professor of the Department of SpeechLanguage Pathology at Universidade Federal de Sergipe, Lagarto-SE, Brazil.

Authors' Contribution:

All authors made substantial contributions to the conception and design of this study, to data analysis and interpretation, and to the manuscript revision and approval of the final version. All the authors assume public responsability for content of the manuscript.

Associate Editor:

Wanderlei Abadio de Oliveira

Received: Oct. 07, 2020

1st Revision: Feb 10, 2021

2nd Revision: Mar. 24, 2021

Approved: Mar. 24, 2021

How to cite this article:

Guedes-Granzotti, R. B., César, C. P. H. A. R., Ribeiro, V. V., Dornelas, R., Moreira, P. P., \& Silva, K. (2021). Teaching methodology, stress and study and learning strategies: Interrelationships among university students. Paidéia (Ribeirão Preto), 31, e3121. doi:https://doi.org/10.1590/1982-4327e3121 